\title{
Pengaruh Kinerja Keuangan Terhadap Nilai Perusahaan Batu Bara
}

\author{
Humera Asad Ullah Khan \\ Universitas Bahaudin Mudhary Madura, Sumenep, Indonesia \\ Email address: \\ humerakhan@unibamadura.ac.id
}

\begin{abstract}
This study aims to examine the effect of financial performance on firm value in the coal sector listed on the Indonesia Stock Exchange for the period 2017-2019. Financial performance in this study is represented by ROA (Return on Assets) and ROE (Return on Equity). Samples were taken using purposive sampling method, obtained 12 coal companies. The results of this study indicate that the ROA (Return on Asset) and ROE (Return on Equity) simultaneously have an effect on firm value. ROE (Return on Equity) partially affects firm value in the coal sector listed on the Indonesia Stock Exchange for the 2017-2019 period.
\end{abstract}

Keywords: ROA, ROE, Firm Value.

\begin{abstract}
Abstrak: Penelitian ini bertujuan untuk menguji pengaruh dari kinerja keuangan terhadap nilai perusahaan pada sector batu bara yang terdaftar di Bursa Efek Indonesia periode 20172019. Kinerja Keuangan didalam penelitian ini diwakilkan oleh ROA (Return on Asset) dan ROE (Return on Equity). Sampel diambil dengan menggunakan metode purposive sampling diperoleh 12 perusahaan batu bara.Hasil dari penelitian ini menunjukkan jika ROA (Return on Asset) dan ROE (Return on Equity) secara simultan berpengaruh terhadap nilai peusahaan. ROE (Return on Equity) secara parsial berpengaruh terhadap nilai perusahaan pada sector batu bara yang terdaftar di Bursa Efek Indonesia Periode 2017-2019.
\end{abstract}

Kata Kunci: ROA, ROE, Nilai Perusahaan.

\section{PENDAHULUAN}

Persaingan didalam dunia usaha yang sering terjadi saat ini menjadikan para pemangku kepentingan mengunakan strategi yang tepat dalam mendukung kegiatan kegiatan operasional pada perusahaan yang mereka jalankan. Tujuan yang paling mendasari didirikannya perusahaan adalah untuk terus memaksimalkan kekayaan para share holder dengan cara terus memaksimalkan laba dan harga saham dari perusahaan yang dimiliki. Dengan mencetak laba setinggi tinggi sesuai dengan tujuan utama didirikannya perusahaan maka perusahaan dapat berbuat banyak untuk terus mensejahterakan para pemilik saham, karyawan dan meningkatkan potensi produk baru dan terus melakukan investasi baru.

Investasi dikatakan perjanjian diatas sejumlah dana ataupun sumber daya lain yang dilaksanakan disaat sekarang ini yang bertujuan utamanya memperoleh sejumlah keuntungan yang terbilang pada masa yang akan datang (Tandelilin, 2013). investasi 
merupakan penangguhan dari konsumsi dilakukan pada saat ini yang untuk dialihkan kepada aktiva produktif dalam rentan periode waktu yang tertentu. Pihak - pihak yang sedang melaksanakan kegiatan investasi dikenal sebagai investor. Investasi dilaksanakan dengan beragam sarana salah seperti dengan melakukan investasi di capital market. Pasar modal dikatakan sarana dimana terjadi transaksi jual dan beli diantara pihak perusahaan \& pihak investor dengan tujuan mendapatkan keuntungan (Jogiyanto, 2011).

Investasi diartian sedangkan penundaan untuk konsumsi dimasa saat ini untuk dialihkan kepada aktiva produktif dalam rentan waktu yang tertentu. Investasi merupakan kesepakatan dari sejumlahdana maupun sumber daya yang lain nya yaang dilaksanakan paada sekarang inii yang bertujuan untuk mendapatkan sejumllah tingkat keuntungan untuk masa yang akan datang (Sunariyah, 2016). Investor jika membeli saham pada saat ini memiliki harapan untuk mendapatkan pengebalian dana yang menguntungkan dari kenaikan akan harga dari saham maupun sejumlah dari dividen pada masa mendatang. Investasi bisa dikelompokkan berurut ragamnya berupa investasi yang dilakukan secaraa langsung (direct investment) danjuga investasi yan dilakukan secara tidak langsung (indirect investment) (Zen, 2013).

Indirect Investment diartikan investasi yang dilakukan bukan terhadap aset ataupun factor produksi, melainkan dilakukan terhadap aset bidang keuangan (financial assets), misalnya deposito, surat berharga (sekuritas) disebut saham ataupun obligasi, CP (Commercial Paper), reksa dana danjuga lain sebagaiinya. indirect investment memiliki tujuan untuk memperoleh benefit padamasa yang akan datang. benefit masa yang akan datang pada indirect investment ini dikenal dengan istilahnya berupa balas jasa investasi yang dinamakan dividen ataupun capital gain (Kho, 2019). indirect investment pada akhirnya pula dijadikan agar meningkatkan pengembangan Direct investment. Investasi berhubungan dengan banyak sekali aktivitas. Dalam berinvestasi sejumlah dana atas aset riil ataupun aset finansial adalah salah satu aktivitas investasi yang pada umumnya maupun banyak dilakukan pada saat ini (Tridianti, 2014).

Perkembangan perekonomian dapat dicermati dari beragam macam cara, misalnya dengan menggunakan informasi mengenai berapa besarnya atau banyaknya perkembangan investasi yang terjadi dipasar modal. Untuk para Investor, melakukan tindakan investasi di pasar modal adalah salah satu dari langkah yang diambil untuk meningkatkan pemasukan ataupun pendapatan mereka (Seng, 2017). Berinvetasi dipasar modal ini tentunya menawarkan return yang tergolong tinggi jika dibandingkan dengan tawaran deposito yang di tawarkan oleh pihak bank.

Pasar Modal merupakan perantara yang digunakan oleh perusahaan untuk menjual sahamnya kepada masyarakat umum. Selain itu pasar modal merupakan termasuk pada financial market yang memiliki beberaapa fungsi salah satunya untuk mendistribusikan kelebihan dana yang dimiliki oleh pihak yang mempunyai dari kelebihan akan dana yang didisribusikan untuk pihak dimana merasa memerlukan adanya tambahan dana (Nurul, 2017). Pihak yang memerlukan dana ini diwakilkan oleh perusahaan yang menjadikan pasar modal sebagai sarana untuk menghimpun dana dengan cara menerbitkan obligasi, atau instrument lainnya.

Melakukan Investasi di pasar modal ini sifatnya penting bagi perusahaan, dikarenakan perusahaan bias menjalankan kegiatan dalam usahanya, akan tetapi kegiatan berinvestasi ini 
cenderung memiliki tigkat risiko dan juga mengandung ketidakpastian dan juga acapkali terlalu sulit untuk ditaksirkan oleh para calon investor maupun investor itu sendiri (Ulupui, 2016). Para Investor melakukan berbagai macam cara agar mereka bias memprediksi tingkat risiko sekecil mungkin dengan mengguakan berbagai macam sumber informasi mengenai perusahaan yang mereka targetkan untuk berinvestasi (Kusuma, 2012). Perusahaan yang sudah melantai di pasar modal, di wajibkan untuk melaporkan hasil dari laporan keuangannya dan mempublikasikannya secara rutin. Hal ini dilaksanakan guna memberikan informasi yang transparan kepada para investor dan juga teruntuk para calon investor.

Laporan keuangan menggambarkan tanggung jawab dari manajemen suatu perusahaan yang di tujukan kepada pihak dalam perusahaan maupun pihak luar perusahaan mengenai dari hasil kerja untuk perusahaan dalam waktu satu periode. Tergambar oleh financial report yang tersaji selanjutnya para share holder untuk melaksanakan penilaian teruntuk saham perusahaannya. Hal ini sama Seperti yang dihasilkan oleh (Zen, 2013), yang didukung juga oleh pernyataan (Sudiyono, 2018) jika laporan keuangan yang diperoleh adalah didasari oleh siklus dari akuntansi yang dilakukan dengan proses yang dianggap benar maka diperkirakan akan sedikit meredam munculnya bersitegang diantara para pihak yang memiliki posisi penting diperusahaan tersebut.

Informasi yang tergambar jelas didalam laporan keuangan dianggap kurang cukup menampilkan informasi yang signifikan andai belum dilakukannya analisis lanjutan, adapun pilihan dari analisis yng dilakukan ialahberwujud analisis dari rasio keuangan. Analisis yang dilakukan terhadap rasio keuangan ini menghasilkan suatu analisis yang mana mengcompare antara tampilan dari angka-angka yang terlapor didaalam laporan keuangan dari suatu perusahaan. Jika berdasarkan pada rasio dari keuangan yang dianggap bias dipergunakan adar dapat memperkirakan masalah yang dimiliki dari keuangan suatu perusahaan, dan juga prospek dari suatu perusahaan untuk yang akan terjadi kedepannya (Safitri, Sinarwati, 2015).

Para Investor baru dengan kehadirannya diharapkan dapat untuk meningkatkan kinerja keuangan perusahaan. Sebelum memutuskan untuk melaksanakan Investasi para calon investor tentunya mengamati laporan keuangan yang di publikasikan oleh perusahaan. Didalam laporan keuangan ini akan mencerminkan jika berusahaan sedang dalam kondisi bain maupun tidak, dan juga apakah sebuah perusahaan mempunyaikinerja yang dikatakan efektiif dan juga dikatakan efisien didalam mengelola pasokan dana yang diperoleh dari internal ataupun ekternal perusahaan pada periiode tertentu.

Kinerja dari keuangan tentunya dilihatkan melalui hasil-hasil dari perhitungan atas proses akuntansi yang digunakan yang normalnya dikenal laporan keuangan (Siwi, 2016). Informasi yang diperoleh atas laporan dari keuangan tersebut memiliki fungsi selain dikenal akan sarana untuk bertukar informasi, dan pula sebagaii alatt atas pertanggung jaawaban yang dilakukan manajemen yang ditujukan untuk para pemilik dari perusahaan dan pula menjadi gambaran atasindikator akan keberhasilan suatu perusahaan dan juga digunakan sebagai salah satu dari bahan pertimbangan dalam pengambilan keputusan. Itu sebabnya para investor ini umumnya mempergunakan informasii tersebut sebagaii tolak ukur yang digunakan didalam melaksanakan transaksi jual dan juga beli suatu perusahaan (Zebua, 2015).

Kinerja keuangan umumnya diukur dengan mempergunakan rasio keuangan. Rasio keuangan mencerminkan perubahan yang terjadi didalam keuangan perusahaan dan juga 
seberapa besar potensi suatu perusahaan didalam mengelola kekayaan yang dimiliki oleh sebuah perusahaan yang nantinya dapat untukmeningkatkan nilai perusahaan. Keberhasilan suatu perusahaan didalam mengelola sumber dayanya juga dicerminkan didalam nilai perusahaan, bisa dikatakan jika nilai perusahaan menjadi salah satu bahan pandangan bagi para investor sebelum menginvestasikan kelebihan dana yang dimilikinya di perusahaan tersebut. Jikalau semakin banyak dari investor membeli saham dari perusahaan tersebut maka hal ini akan berakibat atas naiknya hargasaham dan juga nilaiperusahaan tersebut. Naik maupun turunnya harga dari suatu saham perusahaan menjadikan penentu bagi nilai perusahaan dari sudut pandang investor.

Telah banyak penelitian yang dilaksanakan mengenai faktor kinerja keuangan terhadap nilai perusahaan yang dilaksanakan, namun yang menjadikan penelitian ini tentunya berbeda dibandingkan penelitian yang sebelumnya telah dilaksanakan ialah sector batu bara yang terdaftar di bursa efek Indonesia periode 2017-2019 dipilih peneliti karena hal ini mencerminkan kondisi terbaru dimana sector batu bara kian diminat oleh para investor dan kondisi keuangannya cenderung stabil. Didalam penelitian ini peneliti menambahkan variable bebas berupa kinerja keuangan yang kemudian dihitung dengan mempergunakan Rasio keuangan yang terdiri atas ROA (Return on Asset) dan juga ROA (Return on Equity). Variable ROA yang digunakan sebgain indikator pengururan efiseinsi perusahaan didalam mengelola asett yang dimiliki.Kemudian variable ROE digunakan untuk mengukur efektivitas dari perusahan didalam mengelola modal yang dimiliki. Didalam penelitian ini peneliti menggunakan variable independent berupan kinerja keuangan dan variable dependennya berupa nilai perusahaan.

Penelitian yang telah dilaksanakan oleh (Anindiyati, 2011) memperoleh hasil jika kinerja keuangan memiliki terhadap nilai perusahaan. Hal ini tentunya diidukung oleh penelitian yangsudah dilaksanakan oleh (Wahyu, 2014). Namun penelitiian yang dilaksanakan oleh (Anggitasari, 2012) memperoleh hasil yang berbeda dimana didalam penelitannya disebutkan jika variable ROA dalam penelitian tersebut tidak memiliki peengaruh terhadap nilai perusahaan. (Wahyu, 2014) didalam penelitiannya menyebutkan jika ROA dan ROE memiiliki pengaruh secara signifikan terhadap nilai perusahaan. Dengan adanya berbedaan hasil penelitian yang telah dijabarkan maka mendorong peneliti untuk melaksanakan penelitian teentang Pengaaruh Kinerja Keuangan Terhaadap Nilai Perusahaan Batu Bara 2017-2019.

\section{KAJIAN TEORI}

\section{Kinerja Keuangan}

Laporan Keuangan. Laporan keuangan ialah suatu penyajian atas laporan yang terdiri dari kedudukan financial begitupun terhadap kinerja dari keuangan dari suatu subjek. Laporan keuangan yang sudah dipublikasikan oleh suatu perusahaan harus dapat membuka keadaan dari perusahaan yang sebenar benarnya, yang pada akhirnya dapat bermanfaat bagi masyarakat pada umumnya. Informasi yang dianggap berfaedah terhadap pengambil kepuutusan harus lah meliputi informasi yaang memiliki keterkaitan. Salah satu yang menjadi jikalau suatu penjelasan akuntansi yang signifikan adalah adanyareaksi dari pemodal pada saat dipublikasikannya suatu informasi yang tentunya ditunjukkan dengan adanya aktivitas dari harga saham (Tandelilin, 2013). 
Tujuan Laporan Keuangan. Laporan keuangan merupakan salahsatu acua utukpara investor untukberinvestasi diperusahaan tersebut maupun tidak. Hal ini dikarenakan didalam laporan keuangan mencerminkan prestasi dari perusahaan dimasa lampau dan juga laporan keuangan menjadi petunjuk dimasa yang akan datang didalam menerapkan suatu kebijakan (Wahyu, 2014). Informasi yang di cerminkan didalam laporan keuangan harus transparan dan benar adanya, halini dikarena kan Laporan keuangan menjadi penyedia informasii bagi para calon investor maupun para investor. Secara umum tujuan dari laporan keuangan ialah memberikan infoormasi posisis keuangan, kinerja keuangan, arus kas perusahaan yaang berguna teruntuk kelompok peengguna didalam pilihan untuk membuat keputusan ekonomi serta mencerminkan tanggungjawab dari manajemen didalam mengelola sumber daya yang telah dipercayakan (Ari, 2013). Secara Khusus Laporan keuangan menyajikan data tentang kekaayaan, kewajiban bersih, kekayaan bersiih, perubahan kekayaan dan kewajiiban, proyeksi laba, dan juga informasi relevanlainnya (Nuraeni, 2019).

Pengguna Laporan Keuangan. Pengguna yang berkepentingan dengan laporan keuangan meliputi: Pemberii piinjaman, pemasok danjuga krediitur, pelanggan, masyarakat, pemeriintah dan iinvestor (Andini, 2016).

Ukuran Kinerja Keuangan. Umumnya Teknik analisis yang digunakan didalam penliaian investasi bersifat fundamental, analisis teknikal, analissis ekonomi, danjuga rasio dari keuangan (Sianturi, 2015). Rasio keuangan berdasarkan ruanglinggkupnya dikelompokkan mejadi lima jenis. Rasio likuiditas dimana rasio ini merupakan kemampuan dari perusahaaan untukk memenuhi atas kewajibannya. Rasio keuangan tersebut terdiri atas Quick Ratio (QR), Net Working Capital, dan Current Ratio (CR). Rasio Aktivitas dimana rasio keuangan ini mencerminkan keemampuan dari suatuperusahaan didalam memanfaaatkan kekayaan yang telah dimiliikinya.. Rasio Ini terdiri atas Tottal Asset Turnover (TAT), Fixed Asset Trunover, Inventory Turn Over, Average Trunover, Average Collection Period, dan juga Day's Sales Inventory. Rasio Solvabilitas dimana rasio ini mencerminkan kemaampuan dari perusahaan didalam memenuhi atas kewajiiban jangkaa panjangnya. Rasio ini terdiri atasDebt Ratio, Debt to Equity Ratio, Cash Flow Interest Coverage, Cah Return on Sales. Rasio Pasar dimana rasio keuanganini mencerminkan informasi penting perusahaan yang kemudian diungkapkan didalam basis per saham. Rasio keuanganini terdiri atas Devidend Yield, Devidend Per Share, Price Earning Ratio, Earning Per Share, Price to Book Value (Marsandy, 2018). Terdapat dua jenis kinerja perusahaan yang digunakan sebagai tolak ukur, kinerja pasar dan juga kinerja operasi. Pengukuran kinerja operasi perusahaan dilihat dari kemampuan perusahaan yang tercermin didalam laporan keuangan. Kinerja operasi diukur dengan menggunakan Rasio Profitabilitas. Rasio yang paling sering digunakan ialah ROA (Return on Asset) dimana rasio ini mencerminkan keuantungan dari bisnis dan juga efisiensi perusahaan didalam memanfaatkan total asset yang dimiliki perusahaan. Rasio tersebut menjadi wakil dari rasiio profitabiilitas, Semakin tingginya nilai ROA maka diartikan semakin efisien perusahaan didalam menggunakan asset-aset yang dimiliki dan menghasilkan keuntungan bagi perusahaan (Yudi, 2019). 
Nilai Perusahaan. Nilai perusahaan ialah harga yang beersedia diibayarakan oleh paracalon pembeli Ketika perusahaan tersebut akan dijual (Husnan, 2015). Didalam penelitian ini nilai perusahaan diartika sebagai nilai pasar dimana jika nilai perusaahan meningkat maka hal ini menjadikan harga saham meningkat yang kemudian berdampak sebagai kemakmuran bagi pemegang saham (Mudjijah, 2019). Pada umumnya ppara pemodal memberikan kuasa pengelolaan kepada para professional dalam hal ini manajer maupun komisaris untuk mencapai nilai yang tinggi (Rusli, 2014). Nilai perusahaan ialahkonsep yang sangat pentiing bagi investor dimana nilai perusahaan merupakan indiikator pasar untuk meniilai perusahaan yang dilakukan menyeluruh, ataujuga bisa disebutkan jika nilai perusahaan merupaakan hargayang harus diayarkan oleh para calon pembeli Ketika nantinya perusahaan tersebut akan dijual (Mardiana, 2016).

Pengertian Saham. Harga saham merupakan gambaran harga akansuatu saham yang dimiliki oleh pasar yang sedaang berlaangsung saat ini di bursa efek. Para share holder diharapkan mendapatkan return terhadap modalnya yang mana disebut dengan dividen dan juga capital gain (Sunariyah, 2016). Tingginya harga dari saham ini tentunya akan memberikan pengurangan atas kemungkinan dari para calon investor untuk membeli harga dari saham tersebut. Adanya law of supply and demand yang berlaku danjuga sebagai imbal baliknya haarga saham yang terbilang tinggi tersebut akan mengalami penurunansampai dengan terciptanya posisi atas keseimbangan yang terbilang baru (Putri, 2013).

Harga Saham dikatakan cerminan dari nilai dari suatu perusahaan. Jikalau suatu perusahaan memiliki kinerja cakap dan perusahaan dapat terus mencapai tujuan yang menghasilkan laba yang tinggi, maka perusahaan tersebut tentunya menjadi incaran para investor yang ingin berinvestasi. Prestasi yang baik yang telah diperoleh oleh perusahaan tercermin dari laporan keuangan yang telah dipublikasikan secara umum sehingga dapat menarik minat dari para investor itu sendiri.

Didalam melaksanakan investasi berwujud saham penting dilaksanakannya analisis untuk menakar nilai saham, analisis yang dipergunakan berupa analisis fundamentaldan jug analisis teknikal. Target dari analisis fundamental ialah untuk memastikan apakahnilai dari saham sedang berada diposisi undervalue ataupun overvalue. Saham bisa disebutsebagai undervalue apabila haarga saaham di pasar saham lebiih keciil dibanding hargayang wajar, demikian juga dengan sebaliknya (Suhairy, 2016). Untuk beritahu jikalau untuk memperediksi harga saham dapat dilakukan dengan mempergunakan analisis fundamental yang mana menganalisa keadaan dari financial maupun ekonomi atas suatu perusahaan yang mempublikasikan sahamnya. Analisis yang dapat dilakukan ini terdiri atas trend penjualan serta laba dari perusahaan, kualitas dari produk, posisi persaingan perusahaan yang berada di pasar, hubungan kerja diantara pihak perusahaan dengan karyawannya, sumber bahan mentah, peraturan-peraturan dri perusahaan dan juga beberapa faktor-faktor lainnya yang dapat pula mempengaruhi nilai dari saham perusahaan tersebut (Budiantara, 2013).

Analisis fundamental erat kaitannnya terhadap evaluasi pencapaian perusahaan, baik efektifitas maupun pendayagunaan dari suatu perusahaan didalam menggapai goalnya(Rimbani, 2013). Untuk dapat menganalisis pencapaian dari suatu perusahaan dapat juga mempergunakan rasio keuangan yang tersusun didalam 4 bagian, Rasio tersebut berupa rasio likuiditas, aktivitas, hutang, dan profitabilitas (E. I. Sari, Safitri, \& Ekawati, 2014). Menggunakan analisis yang telah disebutkan, para penganalisa ini mencoba mentaksirkan 
harga saham untuk masa mendatang dengan menghitung akan kuantitas dari faktor-faktor fundamental yangmana erat kaitannya dalam menyesuaikan hargadari saham untuk masa yang mendatag dan menetapkan korelasi diantara faktor-faktor yang telah disebutkan kemudian akan diperoleh taksiran harga saham (Wahyudi, 2019).

Dalam istilah umum yang diketahui faktor-faktor fundamental acapkali masuk sebagai bahan penelitian ini diantaranya nilai intrinsik, nilai pasar, Return On Total Assets (ROA), Return On Investment (ROI), Return On Equity (ROE), Book Value (BV), Debt Equity Ratio (DER), Deviden Earning, Price Earning Ratio (PER), Deviden Payout Ratio (DPR), Deviden Yield, dan likuiiditas saham. Analisis teknikal yang mempergunaandata dari pasar yangtelah diterbitkan diantarnya harga saham, volume peerdagangan, indeks harga saham individual ataupungabungan yang digunakan sebagai usaha menyalurkan permintaan dan penawaran saham tertentu ataupun pasar dengancara menyeluruh. (Siwi, 2016), mengemukakan pendapat jikalau pendekatan dalam hal ini pada point nya membuat serta menggambarkan grafik dari saham diamati dan pergerakan harga saham dan juga kapasitas untuk transaksinya agar peneliti memperoleh suatu markah teruntuk tujuan akan adanya transformasi di masa yang mendatang.

Hubungan Kinerja Keuangan dengan Nilai Perusahaan. Dari laporan keuangan yng di gunakan rasio keuangan maka dapatdiketahui jika perusahaantersebut telah berjalan efektif dan efisien ataupun tidak.Rasio keuangan yang dipergunakan didalampenelitian saatini adalah ROA dan ROE yang dijadikan alatukur tingkat keefisienan dan keefektifitasan dari kinerja keuangan suatu perusahaanyang memiliki pengaruh didalam meningkatkan nilai perusahaan (Sen, 2013). Tinggi maupun rendahnya nilai perusahaan menjadikan hal ini sebagai tolak ukur bagi investor untuk keputusan berinvestasi. Nilai perusahaan didalam penelitian saatini di cerminkan dengan nilai pasar. Nilai perusahaan didalam penelitian ini kemudiandihitung mempergunakan rumus Tobin's Q.

\section{METODELOGI}

Perusahaan Batu Bara yang listing di BEI periode pengamatan 2017-2019 dimana berjumlah 25 perusahaan telah menjadi populasi untuk penelitian ini . Perusahaan Batu bara yang selalu mengalami perkembangan ini tentunya akan memperoleh perhatian yang lebih dan juga nilai jual yang berakibatkan akan membentuk arah tersendiri untuk para investor untuk melakukan investasi dipasar modal. Industri Batu Bara telah dikonfirmasi sangat Tangguh sejauh masa pengamatan pasca efek dari krisiis global yang telah terjadi tahun 2008. Adnyahal ini tentunyatelah menjadi bukti pasca terjadinya krisis global pada tahun 2008 harga dari saham pada sektor Batu Bara disebutkan telah tetap dan juga terus mengalami peningkatan per tahunnya.

Penggunaan dari sampel yang diteliti ini akan ditentukan oleh purposive sampling dengan mempergunakaan 3 patokan seperti berikut: (1) Perusahaan Batu bara listing di BEI dalam periode penelitian 2017-2019, (2) Perusahaan Batu bara yang dijadikan objek penelitian tersebut juga sudah mempublikasikan untuk laporan dari keuangan tahunan perperiode pengamatan tahun 2017-2019. (3) Perusahaan yang digunakan sebagai sample mempunyairasio keuangan lengkap ROA, danjuga ROE danjuga mempunyai sajian data yang cukup lengkap mengenai penguukuran atas nilai perusahaan. Maka jika didasarkan 
pada kriteria yang sudah dijabarkan diatas maka telah diperoleh 12 perusahaan sebagai sampel penelitian.

Identifikasi Variabel. (1) Nilai Perusahaan (Y) ini adalah variabel terikat yang diperhitungkan didalam penelitianini.Nilai perusahaan didalam penelitian yang dilaksanakan ini dihitung dengan menggunakan metode Tobin's Q. Metode Tobin's Q telah dikembangkan oleh James Tobin yang mana metode ini digunakan untuk mengukur nilai perusahaan dengan mencerminkan kinerja manajemen didalam mengeelola asset yang telah dimilikii oleh perusahaan (Sungkono, 2019). Tobin's Q dihitung dengancara membagii antara EMV danjuga Nilai Buku dari total hutang atas EBV kemudian niilai buku total hutang. Dihitung dengan menggunakan rumus:

Tobin's $\mathrm{Q}=\frac{(\mathrm{EMV}+\mathrm{D})}{(\mathrm{EBV}+\mathrm{Debt})}$

Keterangan:

$\mathrm{EMV}=\mathrm{P}($ Closing Price $) \times \mathrm{Q}$ (Jumlah Saham yang beredar)

Debt $=$ Nilai buku dari total hutang

$\mathrm{EBV}=$ Nilai buku dari total asset

(2) ROA (X1), ROE (X2) adalah bagian diantara variabel bebas berupa kinerja keuangan yang digunakan didalam penelitian ini. Variabel bebas ini merupakan variabel yang berpengaruh terhadap perubahan dari variabel terikat. Disebutkan rumus untuk melakukan perhitungan atas rasio-rasio tersebut dinyatkan sebagaii berikut:

Return on Asset $\quad=\quad$ Laba bersih setelah pajak

Total Aset $\quad \mathrm{X} 100 \%$

Return on Equity $=\frac{\text { Modal Sendiri }}{\text { Laba Bersih Setelah Pajak }}$

$\mathrm{X} 100 \%$

Sumber dan Metode Pengumpulan Data. Jenis dari data yang di pergunakan daalam studi ini ialah data kuantitatif dimana berasal darii situs resmi Bursa Efek Indonesia www.idx.co.id tahun 2017-2019. Data yaang dipergunakan ialah laporan laporan keuangan tahunan pada periode penelitian 2017-2019 pada perusahaan sector Batu Bara yang Listed di Bursa Efek Indonesia. Metode pengumpulan data penelitian ini mempergunakan metodedokumentasi, dimana metode ini mengumpulkan data-data penelitian melalui pihak ketiga seperti Badan pusat Statistik, pojok Bursa Efek Indonesia dan juga Indonesian Stock Exchange (IDX). 
Teknik Analis Data. Metode Analisis data yang di pergunakan di dalam penelitian iini meliputi ujii asumsi klassik, analisis regresi, dan juga pengujian atas hipotesis. Didalam menganalisis data maka peneliti mempergunakan program aplikasi SPSS 22. Program aplikasi SPSS digunakan karena software ini merupakan pengolah data statistic yangsudah biasa dipergunakan dalam biidang bisnis dimulai dari pengolahan yangbersifat sedehana hingga bersifat sangat kompleks. Tampilan dari SPSS tentunya setara dengan aplikasi Ms. Excel bahakan pengelolaan grafis dari SPSS sudah melebihi software tersebut (Kusuma, 2012)

Pengujian Asumsi Klasik. Pengujian ini memiliki tujuan Unuk mengetahuii danjuga menguji atas kelayakan dari model reegresi yang dipergunakan didalam penelitian ini dan juga dimaksudkaan untum memastiikan jika didalam model yang dipergunakan tidak ditemukan multikolininieritas dan heteroskedastisitas, kemudian untuk memastikan jika data yang dipergunakan di dalam penelitiian ini berdistribusi normal (Ghozali, 2012).

Uji Normalitas Data. Uji Normalitas Data diilaksanakan dengantujuan didalam model regresi variable residual mempunyai distribusii normal atau tidak. Penguujian ini perlu dilksanakan karenauntuk melaksanakan uji T danjuga F mrngansumsikan jika nilaii residual mengikutii distribusi normal (Nuraeni, 2019). Normalitas tentunyadapat diprediksi dengan cara melihat dari pola penyebaran titik titiik paada sumbu diaagonal yang terdapat pada grafik ataujuga kita bisa melihatnya pada histoogram dari residualnya. Untuk melihat hal tersebut maka kriiteria yang dipergunakan ialah:

Apabila dataa menyebar pada sekitaran garis diagonal kemudian mengikutii arah dari gariis diagonal ataupun dari grafikhitogramnya mencerminkan poa distriibusi normal, makamodel regresi dikatakan memenuhii asumsii normalitas.

Apabila data menyeebar dengan jarak yang jauh daridiagonal ataujuga tidak mengikutii dari arah garis diagonal ataupun grafik histogramnya tidak mencerminkan polaa distribusii normal, makaa dikatakan model egresi tidak memenuhi asumsi normalitas.

Agar terhindar dari kesalahan membaca grafik, maka diperlukanuji statistic non parametrik Kolmogorov Smirnov dengan hipotesis:

$\mathbf{H}_{\mathbf{0}}$ : Data residual berdistribusi normal

$\mathbf{H}_{\mathbf{a}}$ : Data Rresidual tidak berdistribusi normal

Uji Heteroskedastisitas. Uji ini dilaksanakan untuk melihat jika didalam model regesi terjadi kesamaan ataupun tidak dari residual pada satu pengamatan ke pengamatan lainnya (Habiburrahman, 2015). Model regresi yang dikatakan baik jika tidak di temukan heteroskedastisitas. Heteroskedastisitas dapat dilihat dengan mengamati grafik plot antara nilai prediksi dari variable dependen dalam hal ini ZPRED dengan residual dalam hal ini SRESID. Deteksi dari ada atau tidaknya pola tertentu pada grafik scatterplot diantara SRESID dan ZPRED dimana sumbu Y ialah Y yang di prediksi dan sumbu X ialah residual yang telah studentized (Ghozali, 2012). 
Uji Autokorelasi. Pengujian ini dilaksanakan untuk melihat apakah didalam model regresi terbebas dari autokorelasi denga melihatb dari nilai durbinwaston.

Uji Multikolinieritas. Uji ini dilaksanakan utuk mengetahui jika tidak ditemukannya hubungan linier yang sempurna diantara variable-variable indpenden.

Statistik Deskriptif. Pengukuran yang dilakukan didalam pengijuain ini mliputi nilai minimum, nilai maxsimum, mean, dan standar deviasi.

Pengujian Hipotesis. Uji F dilaksanakan untuk mengetahui jika variable independent secara Bersama sama berpengaruh terhadap variable dependen atau tidak.

Uji Statistik t. Uji ini dilaksanakan pengaruh variable independent dan dependen secara parsial.

Koefisien Determinasi $\left(\mathbf{R}^{2}\right)$. Pengujian ini dilaksanakan untuk mengetahui hubungan diantara variable independent dengan dependen didalam suatu persamaan regresi.

\section{PEMBAHASAN}

Tabel 1. Statistik Deskriptif

\begin{tabular}{l|l|l|l|l|l}
\hline & $\mathbf{N}$ & \multicolumn{1}{|c|}{ Min } & Max & Mean & Std. Dev \\
\hline ROA & 12 & 0,15 & 3,65 & 1,23 & 7,32 \\
\hline ROE & 12 & 5,67 & 8,65 & 1,55 & 2,55 \\
Sumber: (Diolah SPSS22, 2021)
\end{tabular}

Didasarkan pada perolehan table statistic deskriptif maka diperoleh nilaiminimum, nilaii maksimum, niilai raata-rata danjuga standar deviiasi. Nilaii minimum ialah perolehan nilai teerendah dari masing-masiing variable, nilai maksimum ialah perolehan nilai tertingi dari masing-masing variable, nilai rata-rata ialah perolehan rata-rata dari beberapa data, standard deviasi ialaha variasi dari sebaran data yang mana jika nilainya semakin besar sebarannya maka data yang didapatkan akan semakin bervarasi.

Variable Return on Asset (X1) didalam penelitian ini dengan sample (N) 12 perusahaan menghasilkan nilai minimum 0,15 , kemudian nilai maksimum 5,67 dan juga nilai mean 1,23. Santard deviation 7,32. Nilai terendah dimiliki oleh Adaro Energy Tbk. Pada tahun 2020. Sedangkan nilai tertinggi dimilki oleh Perdana Karya Perkasa Tbk. Pada tahun 2020.

Variable Return on Equity (X2) didalam penelitian ini dengan sample (N) 12 perusahaan menghasilkan nilai minimum 5,67, kemudian nilai maksimum 8,65 dan juga nilai mean 1,55. Santard deviation 2,55. Nilai terendah dimiliki oleh Bayan Resources Tbk. Pada tahun 2020. Sedangkan nilai tertinggi dimilki oleh Darma Henwa Tbk. Pada tahun 2020.

Pengujian Asumsii klasiik yang dipergunakan didalam penelitian initerdiri atas uji normalitas, multikolinieritas, uji autokorelasi danjuga uji heterokedastisitas. Dala penelitian ini elah dilaksanakan uji asumsi klasik, normalitas, multikolineritas, autokorelasi, dan heterokedastisitas maka diperoleh hasil jika tidak ditemukan penyimpangan.

Uji Normalitas ini dilaksanakan agar mengetahui jika data yang dipergunakan didalam penelitian ini berdistribusi secara normal melalui komogorov smirnov. Didalam penelitian yang dilakukan oleh (Permatasari, 2018) Uji normalitas dipergunakan untuk melihat jikalau 
data yang dipergunakan didalam persamaan regresi telah terdistribusi secara normal. Uji Kolmogorov Smirnov yang dipergunakan untuk mendapati normalitas dari sebuah data. Ketika nilai signifikan yang diperoleh dari data atas persamaan regresi $>0,05$ dikatakan jika data atas persamaan regresi tersebut telah berdistribusi secara normal. Pengujianini dilaksanakan karenaa untuk melaksanakan uji $\mathrm{T}$ dan uji $\mathrm{F}$ yang mengansumsikan jika niilai residual mengikuti distribusi normal. Hasil dari pengujian Kolmogorov smirnov yang memperoleh data telah berdistribusi normal dikarenakan Asymp.sig (2-tailed) Kolmogorov smirnov dalam penelitian ini 0,214 lebih besar dari 0,05 atau 5\%. Hasil daripengujian ini ditampilkan dalam table uji normalitas di bawah ini.

Tabel 2. Uji Normalitas

\begin{tabular}{ll|r}
\multicolumn{2}{c}{ Kolmogorov-Smirnov Test } \\
\hline $\mathrm{N}$ & & Unstandardized Residual \\
\hline Normal Parameters ${ }^{\mathrm{a}}$ & Mean & 432 \\
& Std. Deviation &, 0000000 \\
Most Extreme Differences & Absolute &, 19475259 \\
& Positive &, 058 \\
& Negative &, 058 \\
Test Statistic & &,- 028 \\
Asymp. Sig. (2-tailed) &, 058 \\
\hline a. Test distribution is Normal. & &, 214 \\
\hline
\end{tabular}

Uji Multikolinieritas. Uji Multikolinieritas ialah test yang dilaksanakan untuk menguji terdapatnya hubungan kolerasi antara variable independent didalam model regresi. Multikolinieritas dilihat dari nilai variance inflation factor (VIF). Jika nilai VIF $<10$ kmudian nilai tolerance $>10$ hal ini menjadikan jika adanya gejala multikolinieritas hal ini berlaku sebaliknya pula. Jika nilai tolerance $<0,1$ dan nilai VIF $>10$ hal ini menandakan jika terjadi korelasi antara variable independent. Nilai tolerance yang dimiliki oleh masigmasing variable independent ialah ROA dan ROE. namun nilai VIF dari masing masing variable tersebut $<10$ 
Tabel 3. Uji Multikolinieritas

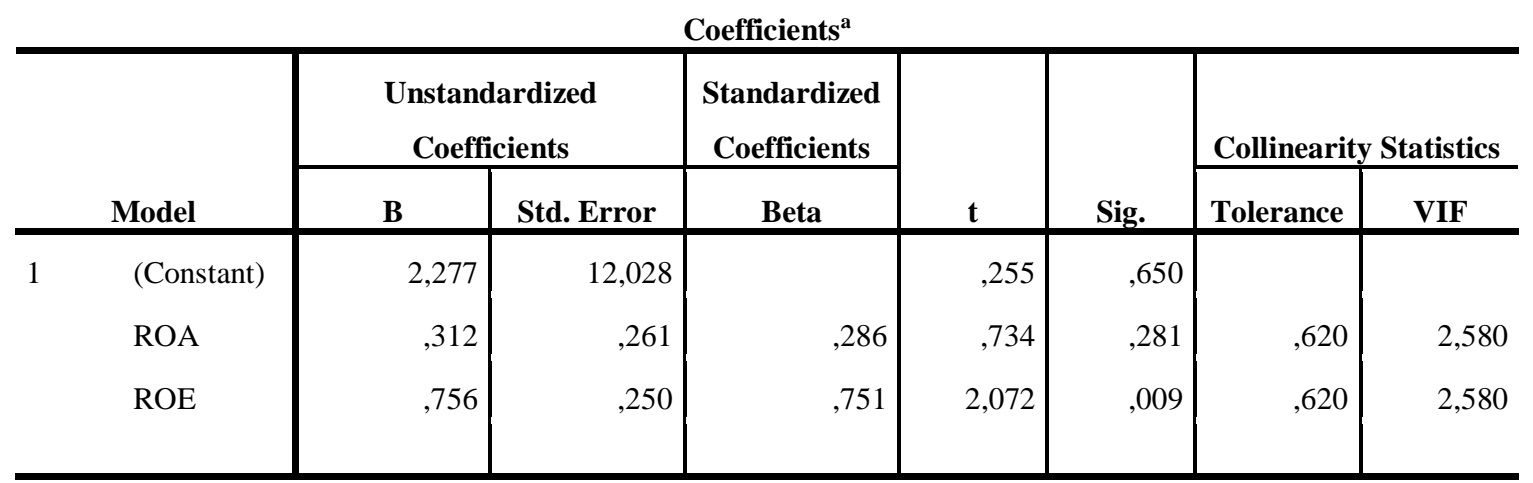

a. Dependent Variable: NILAI PERUSAHAAN

Berdasarkan atas tampilan gambar dari hasil uji normalitas yang di tampilkan diatas tercermin jika nilai VIF (Variance Inflation Factor) pada masing masing independent Variable memperoleh angka $<10$. Untuk Variable ROA dan ROE memperoleh angka 2,580. Jika nilai $>0,10$ dan nilai VIF $<10$ Maka pengujian yang dilaksanakan dinyatakan tidak terdapat multikolinieritas.

Uji Autokorelasi. Regresi yangterbebas dari autokorelasi merupakaln model regresi yang terbilang baik. Ada atau tidaknya autokorelasi di tentukan berdasarkan nilai Durbin-Waston. Autokorelasi akan terjadi jika nilai dari Durbin-Waston mempunyai nilai >5 (Ghozali, 2012). Berdasarkan hasil pengujian yang telah dilaksanakan maka memnghasilkan nilai Durbin-Waston 1,831 yang mana hasil ini <5. Maka disimpulkan terbebas dari autokorelasi.

Tabel 4. Uji Autokorelasi

\begin{tabular}{|c|c|c|c|c|c|c|}
\hline \multirow[b]{2}{*}{ Model } & \multirow[b]{2}{*}{$\mathbf{R}$} & \multirow[b]{2}{*}{ R Square } & \multicolumn{2}{|c|}{ Model Summary $^{\mathbf{b}}$} & \multirow[b]{2}{*}{$\begin{array}{c}\text { R Square } \\
\text { Change }\end{array}$} & \multirow[b]{2}{*}{ Durbin-Watson } \\
\hline & & & $\begin{array}{c}\text { Adjusted R } \\
\text { Square }\end{array}$ & $\begin{array}{c}\text { Std. Error of the } \\
\text { Estimate }\end{array}$ & & \\
\hline 1 &, $403^{\mathrm{a}}$ &, 163 & ,757 & 195434,64800 &, 163 & 1,831 \\
\hline
\end{tabular}

a. Predictors: (Constant), ROA, ROE

b. Dependent Variable: NILAI PERUSAHAAN

Uji heteroskedastisitas. Uji heterokedastisitas memiliki bertujuan untuk menguji data didalam model regresi linier terjadi ketidakcocokan varian antar residual satu pengamatan terhadap lainnya (Permatasari dan Yulianto, 2018). Uji heteroskedastisitas dipergunakan untuk melihat terdapat atau tidak penyimpangan asumsi klasik pada persamaan regresi yang dipergunakan. Heteroskedastisitas adalah terdapat ketidaksamaan varian dari residual terhadap semua pengamatan pada model regresi yang dipergunakan. 


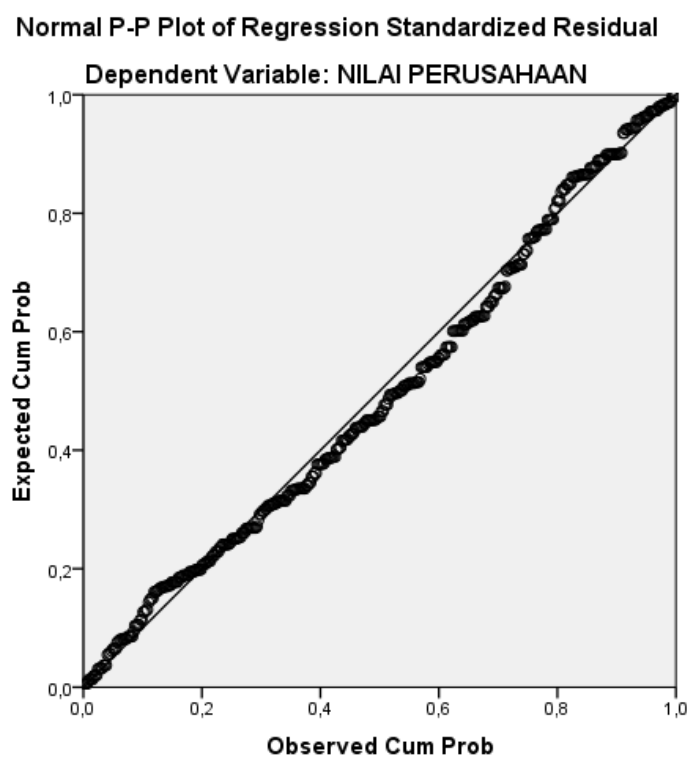

Gambar 1. Uji Heteroskedastisitas

Model regresi yang dikatakan baik ialah yang tidak terdapat heteroskedastisitas. Jika tidak terdapat pola yang cukup jelas seperti adanya titik-titik yang menyebar diatas angka 0 pada sumbu Y, maka disimpulkan jika tidak terjadi heteroskedastisitas. Maka dari tu cara agar mngetahui jika terjadi maupun tidak tejadinya heteroskedastisitas ialah dengen melihat hasil penyebaran titik-titik yang terdapat digrafik. Berdasarkan hasil diatas maka disimpulkan jika penelitian ini tidak ditemukan heteroskedastisitas.

\section{Pengujian Simultan (Uji F)}

Uji F digunakan jika model yang digunakan didalam penelitian ialah model yang dikatakan layak atau tidak. Uji $\mathrm{F}$ juga digunakan agar mengetahui esarnya pengaruh variable independent atas variable depenent secara Bersama-sama (simultan). Uji F dilaksanakan dengan membandingkan $\mathrm{F}$ hitung dengan $\mathrm{F}$ table atas ketentuan :

Ho diterima apabila $\mathrm{F}$ hitung $<\mathrm{t}$ table jika $\alpha=5 \%$

Ha diterima apabila F hitung $>$ t table jika $\alpha=5 \%$

Tabel 5. Uji F

ANOVA $^{\mathrm{a}}$

\begin{tabular}{rl|r|r|r|r|r}
\hline \multicolumn{1}{c|}{ Model } & Sum of Squares & df & Mean Square & F & \multicolumn{1}{c}{ Sig. } \\
\hline 1 & Regression & 441,309 & 2 & 286,654 & 24,567 &, $000^{\mathrm{b}}$ \\
Residual & 102,254 & 429 & 12,005 & & \\
Total & 673,563 & 431 & & & \\
\hline
\end{tabular}

a. Dependent Variable: NILAI PERUSAHAAN

b. Predictors: (Constant), ROE, ROA 
Jika dilihat dari table ANOVA yang terlampir maka dapat untuk diketahuhi apakah variable ROA dan ROE sebagai variable independent memiliki pengaruh langsung secara simultan atas nilai perusahaan (Tobin's Q). Maka dari hasil diatas didapatkan F hitung 24,567 dengan tingkat signifikansi $<0,05$. Hasiil uji $F$ dengan mempergunakan table $F$ mencerminkan nilai dari $\mathrm{F}$ table 2,87. Maka dari hasil yang diperoleh $\mathrm{F}$ table $<\mathrm{F}$ hitung disimpulkan jika variable bebas ROA dan ROE secara Bersama -sama (simultan) berpengaruh atas nilai perusahaan.

Uji T dilakasanakan untuk mengetahui berapa besarnya pengaruh masing-masing variable independent secara parsial ats variable independent. Kriteria-kriteria penetu sebgai berikut:

$\mathrm{T}$ hitung $>\mathrm{t}$ table atau dengan katalain probability < tingkat signifikansi (sig. 0,05), maka disimpulkan Ha di terima dan Ho di tolak. Hal ini berarti jika variable independent berpengaruh secara parsial atas variable dependen.

T hitung $<\mathrm{t}$ table atau dengan katalain probability > tingkat signifikansi (sig. 0,05), maka disimpulkan Ha di tolak dan Ho di terima. Hal ini berarti jika variable independent tidak berpengaruh secara parsial atas variable dependen.

Hasil penelitian ini memperoleh hasil jika variable ROA tidk memiliki pengaruh atas nilai perusahaan. Hal ini dibuktikan dengan hasil darii nilai sig. 0,281 yaang mana nilai ini $>$ dari 0,05 danT hitung 0,734 < hasil T table 2,002543. Kemudian variable ROE memiliki pengaruh atas nilaii perusahaan. Halini dibuktikan dengan hasil sig. 0,009 yangmana nilai ini $<0,05$ dan $\mathrm{T}$ hitung 2,072 $>$ hasil $\mathrm{T}$ table 2,002543.

Koefisien Korelasi ${ }^{\circledR}$ mencerminkan sebeerapa dekatnya titiik kombiinasi antara variable dependen ataupun variable titik bebas dengan variable independent atau bebas atas garis dugaannya (Yuliarni, 2016). Nilai dari $\mathrm{R}^{2}$ (koefisien determinasi) yang diperoleh penelitian ini adalah 0,163 (16,3\%). Dimana hal ini berarti ROA dan ROE yang bertindak sebagai variable independent didalam penelitian ini berpengaruh rendah atau sebesr $16,3 \%$ terhadap perusahaan. Sisa sebsar $83,7 \%$ dipengaruhi oleh faktor-faktor laiinya selain kinerja keuangan didalam penelitian ini peneliti mempergunakan variable bebas ROA dan ROE.

\section{DISKUSI}

Hasiil dari data-data yang dikumpulkan oleh peneliti yang kemudian diolah dengan menggunakan bantuan SPSS kemudian diproses hingga menghasilkan hasil penelitian mencerminkan jika variable ROA tiidak berpengaruuh terhadap nilai perusahaan yang mana hal inii dilihat dari hasil uji $\mathrm{T}$ yang dilaksanakan memperoleh nilai sig. 0,281 yang mana hasil ini > dari 0,05. Namun hasil lain didapatkan dari pengujian terhadap variable ROE memiliki pengaruh terhadap nilai perusahaan yang mana hal ini dilihat dari hasil uji $\mathrm{T}$ yang dilaksanakan memperoleh nilai sig. 0,009 yang mana hasil ini < dari 0,05. Dari hasil ini maka didapatkan jawaban jika variable ROE memiliki pengaruh terhadap nilai perusahaan.

Hasil pengujian secara simultan terhadap Variable ROA dan ROE diperoleh hasil jika kedua variable tersebut berpengaruh terhadap nilai perusahaan. Hal ini dibuktikan dengan uji $\mathrm{F}$ yang menunjukkan nilai dri $\mathrm{F}$ table adalah 2,87. F hitung memperoleh nilai 24,567. 
Hasil ini menunjukkan jika Ftabel < Fhitung sehingga ROA dan ROE berpengaruh secara simultan terhadap nilai perusahaan.

Rasio keuangan didalam penelitian ini ROA dan ROE sepenuhnya tidak dapat digunakan sebagai acuan didalam meniilai pengaruh kiinerja keuangan atasnilai perusahaan di karena kan hasil yang diperoleh dari koefisien determinasi memperoleh nilai yang cukup rendah yaiyu $16,3 \%$ sedangkan sisanya $83,7 \%$ dipengaruhi oleh faktor-faktor lainnya. Sehingga hasil yang didapatkan dari pengolahan rasio keuangan didalam penelitian ini yang diwakilkan oleh ROA dan ROE dikatakan tidaklah cukup jikamewakilkan pengaruh kinerja keuangan terhadap perusahaan Batu Bara yang terdaftar di Bursa Efek Indonesia periode 2017-2019.

\section{KESIMPULAN}

Berdasarkan tehadap hasil yang sudah ditampilkan oleh analisis beserta pembahasan yang telah dijabarkan diatas, maka diperolehlah kesimpulan yang di jabarkan berikut:

Variable ROA tiidak berpengaruh terhadap nilaii perusahaan. Ini ditunjukkan dengan hasil yang diperoleh dari uji $\mathrm{T}$ yang telah pada perusahaan emiten bidang Batu Bara yang terdaftar di BEI pada tahun pengamatan yang dilakukan 2017-2019. Variable ROA memperoleh sig. sebesar 0,281 yang mana hasil ini >0,05. Namun hasil berbeda ditunukkan oleh variable ROE yang memperoleh hasil sig. 0,009 yang mana hasil ini $<0,05$. Perolehan hasil tersebut menunjukkan jika variable ROE berpengaruh terhadap nilai perusahaan pada eminten bidang Batu Bara yang terdaftar di BEI.

Jika diamati nilai keofisien determinasi, maka rasio keuangan yang digunakan didalam penelitian ini yakni ROA dan ROE Secara Simultan (Bersama-Sama) Memiliki pengaruh ter hadap nilai perusahaan Batu Bara yang terdaftar di Bbursa Efek Indonesia. Namun pengaruh yang dihasilkan oleh kedua asio yang menjadi objek penelitian berpengaruh sangat rendah terhadap nilai perusahaan Batu Bara yang terdaftar di Bursa Efek Indonesia dengan nilai $16,3 \%$.

Dari hasil pengujian yang dilaksanakan, maka diketahui jika $83,7 \%$ faktor-faktor lainnya secara bersamaan memiliki pengaruh yang lebih besar terhadap nilai perusahaan selain variable ROA dan ROE yang digunakan didalam penlitian ini.

Dari penelitian yang dilaksanakan maka di dapatkan beberapa keterbatasan yang kemudian dapat menjadi bahan pertimbangan untuk peneliti selanjutnya agar memperoleh hasil yang lebih baik lagi kedepannya. Keterbatasana yang pertama ialah penelitian ini hanya menggunakan perwakilan rasio keuangan yeng berjumlah dua rasiao berupa ROA dan ROE. Kemudian ukurang yang dipergunakan didalam penelitian ini didalam menilai nilai perusahaan sebagai variable terikat dengan menggunakan Tobins'q. Objek yang digunakan didalam penelitian ini berjumlah 12 perusahaan batu bara yang listing di Bursa Efek Indonesia selama periode pengamatan 2017-2019 dengan melalui proses seleksi kriteria tertentu. Tahun yang digunkana didalam penelitian ini terbilang singkat hanya tiga tahun terhitung 2017-2019.

Saran yang kemudian bisa dijadikan bahan pertimbangan untuk mengembangkan penelitian ini ialah dengan menggunakan rasio keuangan lainnya selain ROA hal ini 
dikarenakan variable tersebut tidk memiliki pengaruh terhadap nilai perusahaan pada penelitian ini. Untuk peneliti selanjutnya dapat menambahkan variable rasio keuangan lainnya. Peneliti selanjutnya dapat menggunkann sector yang berbeda dengan tahun pengamatan yang berbeda.

\section{DAFTAR PUSTAKA}

Anggitasari, N., dan Mutmainah, S. (2012). Pengaruh Kinerja Keuangan Terhadap Nilai Perusahaan Dengan Pengungkapan Corporate Social Responsibility Dan Struktur Good Corporate Governance Sebagai Variabel Pemoderasi. Diponegoro Journal of Accounting, 1(1), 692-706.

Anindiyati. (2011). Pengaruh Kinerja Keuangan Terhadap Nilai Perusahaan Dengan Pengungkapan Corporate Social Responsibility Dan Good Coprorate Governance Sebagai Variable Pemoderasi. 1-47.

Ari Lina Wati, N., dan Ayu Darmayanti, N. (2013). Pengaruh Kepemilikan Manajerial Dan Kinerja Keuangan Terhadap Kebijakan Dividen Dan Nilai Perusahaan. E-Jurnal Manajemen Universitas Udayana, 2(12), 253260.

Arviana, N., dan Lapoliwa, N. (2013). Pengaruh ROA, DER, EPS, PER, DAN PBV Terhadap Harga Saham. Ultima Accounting, 5.

Badruzzaman, J. (2017). Pengaruh Earning Per Share Terhadap Harga Saham. Akuntansi, 12(1).

Budiantara, M. (2013). Pengaruh Tingkat Suku Bunga, Nilai Kurs, Dan Inflasi Terhadap Indeks Harga Saham Gabungan Di Bursa Efek Indonesia Periode Tahun 2005-2010. Jurnal Sosiohumaniora, 3.

Darmadji, Tjiptono, dan Fakhruddin. (2016). Pasar Modal di Indonesia. Jakarta: Salemba Empat.

Dewi, P. D. A. (2013). Pengaruh EPS, DER, dan PBV terhadap Harga Saham. E-Jurnal Akuntansi Universitas Udayana, 215-229.

Dwipratama, dan Priana, G. (2015). Pengaruh PBV, DER, EPS, DPR DAN ROA Terhadap Harga Saham (Studi Empiris Pada perusahaan Food and Beverage). Fakultas Ekonomi Universitas Gunadharma.

Ghozali, dan Faruq. (2012). Pengaruh Return on Assets (ROA), Earning Per Share (EPS), dan Debt to Equity Ratio (DER) Terhadap Harga Saham (Studi pada Perusahaan Property yang Listing di Bursa Efek Indonesia Tahun 2007-2011). Pendidikan Fakultas Ekonomi Dan Bisnis, Universitas Brawijaya.

Habiburrahman. (2015). Analisis Pengaruh Rasio Keuangan Terhadap Return Saham (Studi Pada Saham-saham Sektor Agiculture, forestry and fishing yang Terdaftar di Bursa Efek Indonesia Periode 1998-2014). Jurnal Manajemen Dan Bisnis, 6(1), 79-100.

Husnan, Suad, dan Pudjiastuti, E. (2015). Manajemen Keuangan (5th ed.). Yogyakarta: UPP AMP YKPN.

Jogiyanto dan Hartono. (n.d.). Teori Portofolio dan Analisis Investasi.

Kho, B. (2019). Pengertian EPS (Earning per Share atau Laba per Saham) dan Rumus EPS. Retrieved July 6, 2019, from ilmu manajemen industri website: https://ilmumanajemenindustri.com/pengertian-eps-earning-per-share-laba-persaham-rumus-eps/. 
Kusuma, D. (2012). Pengaruh Struktur Kepemilikan Terhadap Nilai Peusahaan dengan Kinerja Keuangan dan Kebijakan Hutang Sebagai Variable Intervening. Siasat Bisnis, 15(1), 27-36. https://doi.org/10.1109/RADAR.2012.6212186

Mardiana, U., dan Ahmad, G. N. (2016). Pengaruh Kebijakan Deviden, Kebijakan Hutang dan Profitabilitas Tehadap Nilai Perusahaan Manufaktur yang Terdaftar di BEI periode 2005-2010. 6(April), 73-84.

Marsandy, C., Deviyanti, D. R., dan Setiawati, L. (2018). Analisis Kinerja Keuangan Perusahaan Sebelum dan Sesudah Go Public pada Perusahaan Sektor Pertambangan yang Terdaftar di Bursa Efek Indonesia. Jurnal Ilmu Akuntansi Mulawarman, 3(4), $1-14$.

Mudjijah, S., Khalid, Z., dan Astuti, D. A. S. (2019). Pengaruh Kinerja Keuangan dan Struktur Modal Terhadap Nilai Perusahaan yang Dimoderasi Variabel Ukuran Perusahaan. Jurnal Akuntansi Dan Keuangan, 8(1), 41-56.

Nugroho, A., dan Axijamo, A. (2015). Business Ethics: Pemahaman Teori Secara Komprehensif dan Implementasinya (A. Arijanto \& D. M. Nastiti, Eds.). Bogor: IPB Press.

Nuraeni, N., dan Berry, Y. (2019). Kebijakan Manajemen Keuangan, Nilai Perusahaan dan Kinerja Keuangan Perusahaan pada Perusahaan Manufaktur di Bursa Efek Indonesia. Jurnal Riset Akuntansi Aksioma, 18(1), 221-254. Retrieved from http://aksioma.unram.ac.id/index.php/aksioma/article/view/60

Nurfadillah. (2013). Analisis Pengaruh Earning per Share, Debt to Equity Ratio, dan Return on Equity terhadap Harga Saham PT Unilever Indonesia Tbk. Manajemen Dan Akuntansi, 12.

Nurul, F. (2017). Analisis Kinerja Keuangan Perusahaan dan Reaksi Pasar Sebelum dan Sesudah Stock Split pada Perusahaan yang Terdaftar di Bursa Efek Indonesia Tahun 2010-2014.

Putri, dan Rachman, T. (2013). Analisis Pengaruh Kinerja Keuangan terhadap Harga Saham pada Perusahaan Manufaktur di Bursa Efek Indonesia. Akuntansi Dan Manajemen.

Rimbani, R. P. (2013). Analisis Pengaruh ROE, EPS, DER dan PBV terhadap Harga Saham Perusahaan RReal Estate Dan PRoperty di Bursa Efek Indonesia Periode 2011-2013. Magister Management Universitas Trumanegara.

Rusli, A., dan Dasar, T. (2014). Pengaruh Rasio Keuangan Terhadap Harga Saham Pada Perusahaan Bumn Perbankan Yang Terdaftar Di Bursa Efek Indonesia. Jurnal Akuntansi, 01(02), 10-17.

Safitri, O., Sinarwati, dan Atmadja, A. T. (2015). Analisis Pengaruh Profitabilitas, Likuiditas, dan Leverage Terhadap Return Saham Pada Perusahaan Manufaktur Yang Terdaftar di BEI Tahun 2009-2013. E-Journal S1 Ak Universitas Pendidikan Ganesha Jurusan Akuntansi S1, 3.

Sari, E. I., Safitri, E., dan Ekawati, R. K. (2014). Pengaruh Faktor-Faktor Fundamental Terhadap Harga Saham PT Unilever Indonesia Tbk. 7.

Sari, M. R., Oemar, A., dan Andini, R. (2016). Pengaruh pertumbuhan perusahaan, ukuran perusahaan, earning per share, current ratio, return on equity dan debt equity ratio terhadap kebijakan dividen. Journal Of Accounting, 2(2), 1-19.

Sen, Y. (2013). Analisis Perbedaan Kinerja Keuangan Sebelum dan Sesudah Initial Public Offering Pada Perusahaan Go Public di Bursa Efek Indonesia. 
Seng, J.-L., Yang, P.-H., dan Yang, H.-F. (2017). Initial public offering and financial news. Journal of Information and Telecommunication, 1(3), 259-272. https://doi.org/10.1080/24751839.2017.1347762

Sianturi, M. W. E. (2015). Pengaruh Kinerja Keuangan Terhadap Nilai. Journal Ilmu Administrasi Bisnis, 3(2), 282-296.

Siwi. (2016). Analisis pengaruh efisiensi modal kerja, likuiditas, dan solvabilitas terhadap profitabilitas pada perusahaan property dan real estate yang go public dibursa efek jakarta pada tahun 1998-2002. Jurnal Administrasi Dan Bisniskuntansi Bisnis.

Sudiyono. (2018). Analisis Pengaruh Efisiensi Modal Kerja, Likuiditas dan Solvabilitas Terhadap Profitabilitas. Universitas Sanata Dharma.

Suhairy, dan Hapcin. (2016). Pengaruh EVA dan Rasio-Rasio Profitabilitas Terhadap Harga Saham. Empirika. Universitas Sumatera Utara.

Sunariyah. (2016). Pengetahuan Pasar Modal (5th ed.). Yogyakarta: UPP STIM YKPN.

Tandelilin, dan Eduardus. (2013). Portofolio dan Investasi Teori dan Aplikasi (1st ed.). Yogyakarta: Kanisius.

Tridianti, dan Ariyana, Y. (2014). Analisis Pengaruh Likuiditas, Leverage, Profitabilitas Dan Ukuran Perusahaan Terhadap Return Saham (Studi Empiris Pada Perusahaan yang Terdaftar di Jakarta Islamic Index/JII). Universitas Jember.

Ulupui. (2016). Analisis Pengaruh Rasio Likuiditas, Leverage, Aktivitas, Dan Profitabilitas Terhadap Return Saham. (Studi Pada Perusahaan Makanan Dan Minuman Dengan Kategori Industri Barang Konsumsi Di BEJ. Jurnal.

Wahyu, A. (2014). Pengaruh Kinerja Keuangan Dan Corporate Social Responsibility Terhadap Nilai Perusahaan Pada Bank. BENEFIT Jurnal Manajemen Dan Bisnis, 18, 57-66. https://doi.org/10.14414/jbb.v5i2.547.

Wahyudi. (2019). Pengaruh efisiensi modal kerja dan likuiditas serta solvabilitas terhadap profitabilitas dan return saham. Akuntable, 16, 134-141. Retrieved from http://journal.feb.unmul.ac.id/index.php/AKUNTABEL

Yudi Sungkono. (2019). Pengaruh Kinerja Keuangan Terhadap Nilai Perusahaan Pada Perusahaan Manufaktur Yang Terdaftar Di Bursa Efek Indonesia. Parameter, 4(1), 116. https://doi.org/10.37751/parameter.v4i1.31

Yuliarni, T., Maryati, U., dan Ihsan, H. (2016). Analisis Kinerja Perusahaan Sebelum Dan Sesudah Initial Public Offering (IPO) Di Bursa Efek Indonesia (BEI). Jurnal Akuntansi \& Manajemen, 11(1), 25-37.

Zebua, G. O. (2015). Faktor-faktor fundamental yang mempengaruhi harga saham perusahaan sektor properti yang terdaftar di Bursa Efek Indonesia. Universitas Terbuka Jakarta.

Zen. (2013). Earning Per share (EPS), Book Value (BV), Economic Value Added (EVA) dan Harga Saham. Manajemen Gajayana, 2, 151-162. 